ELORE (ISSN 1456-3010), vol. 18 - 2/2011.

Julkaisija: Suomen Kansantietouden Tutkijain Seura ry.

[http://www.elore.fi/arkisto/2_11/herranen.pdf]

\title{
AJANKOHTAISTA
}

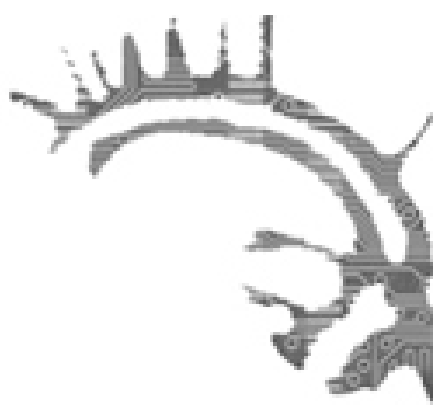

\section{HUUMORIN TUTKIMUKSEN KESÄKOULUSSA}

\author{
Liisa Granbom-Herranen \\ Theory, Research and Applications \\ 11th International Summer School and Symposium on Humour and Laughter \\ Tartto, Viro, 15.-20.8.2011
}

Elokuussa kokoontui Tartossa, Viron Kirjallisuuden Museossa (Eesti Kirjandusmuuseum) järjestyksessä jo yhdestoista huumorintutkimuksen kesäkoulu, 11th International Summer School and Symposium on Humour and Laughter: Theory, Research and Applications. Tämän vuoden kesäkoulussa painottuivat erityisesti eri tieteenalojen huumoria käsittelevä tutkimus teorioineen ja sovelluksineen. Järjestäjien mukaan kiinnostus huumoriin ja erityisesti sen tutkimusten käytännön soveltamiseen ovat lisääntyneet viime vuosina. Huumorintutkimukseen liittyviin tieteenaloihin tutustuminen sekä paneutuminen erilaisiin tutkimuksellisiin näkökulmiin ja menetelmiin olivat viikon aikana keskeisessä osassa. Osallistujia oli useista maista, kuten esimerkiksi Puolasta, Saksasta, Venäjältä ja Suomesta. Joukossa oli sekä pitkän tutkijauran tehneitä että jatko-opiskelijoita.

\section{The International Society for Humor Studies JA KESÄKOULU}

Kesäkoulun taustalla toimii yhdistys The International Society for Humor Studies (IS HS). Vuodesta 1976 lähtien huumorin tutkijat ovat kokoontuneet lähes vuosittain keskustelemaan tutkimuksistaan, joiden kohteena ovat huumori ja sen ilmeneminen niin kirjallisuudessa, puheessa kuin käyttäytymisessä. Yhdistyksen toiminnan kohde on huumori ja sen ilmeneminen tutkimuskohteena. Yhdistyksessä on humanististen tieteiden ohella edustettuina luonnontieteet (erityisesti biologia), käyttäytymistieteet ja yhteiskuntatieteet. ISHS julkaisee myös neljä kertaa vuodessa ilmestyvää aikakauskirjaa Humor: International Journal of Humor Research. Seuraava vuosittainen konferenssi 
järjestetään Krakovassa ensi vuoden heinäkuussa.

Kansainvälisen huumorin tutkimuksen kesäkoulun yleisenä tavoitteena on saattaa yhteen uransa alussa olevat tutkijaopiskelijat, samoin kuin jo pitkän tutkijauran tehneet mutta huumoritutkimuksen parissa aloittelevat tutkijat, jotka tarvitsevat lisätietoa metodologiasta ja teoriasta. Kesäkoulun tavoitteena on tarjota näköaloja huumorin tutkimuksessa käytettyihin lähestymistapoihin kaikille, jotka ovat kiinnostuneita huumorin käytännön sovelluksista. Silmiinpistävä ero moniin seminaareihin oli se, että joillakin luennoitsijoista (kesäkoulun opettajat) oli useita esityksiä, muutamilla jopa viisi luentoa. Kesäkoulu kokoontui esitelmien parissa kuutena päivänä viikossa ja illat kuluivat käytännön sovellutusten parissa. Nämä eivät suinkaan olleet annettuja tehtävïa. Varsinkin komediaillasta jäi kuva, että osallistujien joukossa oli niitä, jotka osasivat hyödyntää tutkimuksessa hankittua tietoa myös koomikkona ja vitsinikkarina. Viikon aikana ehti selvitä myös moni salakieliseltä vaikuttanut ilmaus kuten IR (= incongruity resolution) ja GTVH (= general theory of verbal humour).

Tämän vuoden aiheen mukaisesti kesäkoulussa keskityttiin huumoriin ja nauruun liittyviin aiheisiin, joita tarkasteltiin niin teorioiden, tutkimuksen kuin sovellustenkin näkökulmasta. Huumorin kesäkouluissa on tapana palkita uusia lupaavia tutkijoita. Palkinto ei ole vain nimellinen, alan teoksen lisäksi palkinto tarjoaa ISHS:n tukemana vapaan osallistumisen kesäkouluun kolmena vuotena palkinnon myöntämisestä. Lisäksi joitakin voittajia kutsutaan tuleviin kesäkouluihin luennoimaan aiheestaan. Tänä vuonna palkittiin Bastian Meyerhofer (University of Göttingen) psykolingvistiikan alaan liittyneestä posterista, Tracey Platt (University of Zurich) erilaisia hymyjä käsitelleestä esitelmästä, Maria Goethe (Ludwig Maximilian University of Munich) esityksestä, joka yhdisti huumorin ja musiikin sekä sananlaskugenren sekä vitsailun yhteyttä käsitellyt Piret Voolaid (Viron Kirjallisuuden Museo). Palkinnon myötä seuraava taloudellinen tuki muutamana tulevana vuonna on mielestäni oiva tapa kannustaa jatko-opiskelijoita ja vastaväitelleitä tutkimuksen jatkoon. Sillä myös tuetaan tulevaa osallistumista kesäkoulutoimintaan.

Olin etukäteen olettanut osallistujien olevan ensisijaisesti folkloristeja, toimihan koordinaattorina virolaisten sosialismin jälkeisiin vitseihin erikoistunut folkloristi Liisi Laineste Viron Kirjallisuuden Museosta ja puhujien joukossa olivat esimerkiksi Internetin huumoriperinteeseen erikoistunut folkloristi Arvo Krikmann Viron Kirjallisuuden Museosta, kansanhuumorin tutkijana tunnettu Seppo Knuuttila Itä-Suomen yliopistosta sekä arvoitushuumorin tutkija Piret Voolaid, hänkin Viron Kirjallisuuden Museosta. Suomessahan näkyvä huumorin tutkimus liittyy ennen kaikkea kansanhuumoriin ja lastenperinteeseen. Ennakko-oletukseni osoittautui vääräksi, kesäkoulussa oli edustettuna varsin laaja kirjo tieteitä sekä huumoriin liittyviä osa-alueita, kuten jo palkittujen esitysten aihepiireistä näkyy. 


\section{Puhetta ja ajatuksia huUmorista}

Tilaisuus tarjosi osallistujille mitä mielenkiintoisimman mahdollisuuden tutustua huumorin monialaisuuteen. Osallistujien lähtökohdat ja näkökulmat huumoriin ja sen tutkimukseen poikkesivat toisistaan varsin suuresti. Kukin puhuja luonnollisesti käsitteli aihetta oman tieteenalansa lähtökohdista, vahinko vain, että nämä lähtökohdat ovat tieteenalakohtaisia itsestään selvyyksiä. Yhteisen käsitteistön jäsentäminen osoittautui haasteeksi kuulijalle.

Huumoria ei ole määritelty eikä voida edes tutkimuksen parissa märitellä yksiselitteisesti. Käsite jää aina kulloisenkin tieteenalan ja tutkijan määritettäväksi. Tutkimusalojen välillä on eroja huumorin käsittelyssä, joillakin aloilla tutkimuksen keskittyessä huumorin sisältöön, toisilla sen ilmenemiseen. Joillekin huumori on tutkimusväline. Huumoria haettiin muun muassa kielestä, musiikista, elokuvista, musiikista ja kirjallisuudesta. Huumoria tarjottiin yrityskoulutuksen osana, poliittisena kannanottona ja komediaesityksinä. Huumori ja onnellisuus liitettiin yhteen (Anu Realo, Tarton yliopisto). Huumori tulkittiin nauruna ja siten lihasliikkeinä (Willibald Ruch, University of Zurich). Molemmat mainitut edustavat tieteenalana psykologiaa. Huumoria käsiteltiin synonyymina esimerkiksi komedialle (Holger Kersten, University Magdeburg) ja vitsille (Christie Davies, University of Reading).

Huumoriin kuuluu muutakin kuin naurua, kuten Seppo Knuuttila esitelmänsä otsikolla haastoi: "Onko vakavuus naurun vastakohta?" Knuuttilan esimerkit olivat suomalaisesta lähimenneisyydestä. Mitä tapahtuu, kun autokauppias pyrkii huumoriin ja rinnastaa auton ja naisen? Entäpä kuinka paljon hauskuutta sisältyy sanaleikkiin pääministeriydestä ja kokovartaloministeriydestä? Huumori on vakava asia. Tosin nämäkään esimerkit eivät auenneet kaikille ilman taustoitusta tasa-arvon periaatteista, loukkaamisen ja huumorin välisestä hienoisesta rajasta. Erästä huumorin reuna-aluetta käsitteli Christie Davies puhuessaan ilkeilevästä ja epämiellyttävästä huumorista kirjallisuudesta. Selitettynäkin huumorin aihe jätti ulkopuolelleen kaikki ne, jotka eivät tunne kyseistä aikakautta (esimerkkitapauksessa 1920-luvun Englantia), sosiokulttuurista asetelmaa (luokkajako), silloisia yhteiskuntaluokkia kielenkäyttöineen (kielen vivahteet) sekä kätkettyjä symboleita, joiden kokonaisuudesta syntyy huumori. Kuten useimpien kansainvälisten kokoontumisen, myös kesäkoulun kieli oli englanti. Tässä yhteydessä kielestä syntyi jopa paradoksi: yhtäältä kieli mahdollisti kommunikoinnin ja toisaalta se rajoitti viestintää, sillä käytetyt esimerkit jouduttiin taustoittamaan ja selittämään. Ja kun osa aiheista käsitteli kaskuja ja vitsejä, oli monesta esitelmästä suuri osa lähinnä vitsien selittelyä.

Yllätyksellisyyden luoma huumori rikkoo aina joitakin sääntöjä. Graeme Ritchie (University of Aberdeen) mainitsi vitseilläkin olevan oletetun perustulkinnan, jonka vuoksi siis vitsit tulee ymmärtää oikein. Onko siis väärin ymmärretty vitsi huumoria? Holger Kerstenin mukaan murre käsitetään usein humoristiseksi ilmaukseksi, onhan murteeton kielen käyttö usein oppineiden puhetta. Rikkooko siis murteen käyttö joitakin kielen sääntöjä? Itseäni askarrutti, tutkitaanko huumoria kun tutkitaan komediaesityksiä, joista Sharon Lockyer (Brunel University) puheessaan kertoi. Mielestäni mielenkiintoinen esimerkki ehkä vähemmän tavanomaisesta komedian käytöstä löytyy 
Shazia Mirzan Internet-sivuilta: <http:/ /www.youtube.com/watch?v=TGEY8cZuGF $4 \&$ feature $=$ related $>$. Stand up koomikkona on nuori musliminainen. Tässä yhteydessä mietin, missä kulkee raja kohteen ja sen representaation välillä? Minulle jäi kesäkoulun aiheista kokonaisuudessaan myös kuva huumorista varsin kulttuurisidonnaisena ilmiönä, kuten Christie Daviesin luento varsin selkeästi osoitti.

Verkkokeskustelut perinteen tuotto- ja käyttöympäristönä ovat Suomessa kenties vielä vähemmän tutkittu konteksti. Sekä Viron ja sen lähialueilla tehtävässä että niitä käsittelevässä tutkimuksessa erityisasemassa on entistä Neuvostoliittoa käsittelevä kasku- ja vitsiperinteen tutkimus, jossa on käytetty paljon Internetistä löytyvää materiaalia. Soisin vuonna 2004 julkaistun Arvo Krikmannin toimittaman teoksen "Netinalju Stalinist" tulevan käännetyksi myös suomeksi. Aineistojen keruulle ovat Internet ja yleensäkin sosiaalinen media avanneet aivan uuden väylän.

Esitelmien ulkopuolisella ajalla oli osanottajille tarjolla historiaa ja huumoria. Virallisen ohjelman lisäksi päiviin kuului muun muassa komedian parissa vietetty ilta ravintolassa. Ravintolaesitys keskittyi vitseihin ja tapahtumista kertoviin enemmän ja vähemmän hauskoihin tarinoihin. Lähes mistä tapahtumasta tahansa tulee hauska, kun se kerrotaan hauskasti tai kun yleisö on virittynyt hauskuuksien kuunteluun. Ilta oli minulle elämys, sillä en edes tiennyt ravintoloissa järjestettävistä komediaesityksistä tai siitä, että on olemassa komediaklubeja. Sain kuulla, että Suomessakin on elävä komediaesitysperinne. Kesäkoulu oli tieteellinen tapaaminen, jossa ei kuitenkaan unohtunut käytännön sovellusten testaaminen. Minulle yllätyksenä tuli se kuinka moni huumoria tieteellisesti tutkiva oli myös esiintyvä koomikko!

\section{LOPPU HYVIN, KAIKKI HYVIN}

Kesäkoulu tarjosi ei-huumorin tutkijalle mielenkiintoisen katsauksen huumorin olemuksesta ja huumorin tutkimuksesta. Huumoria ei niinkään pohdittu välineenä kuin artefaktina. Huumoria toki käytettiin esimerkeissä apuna yrityskoulutuksessa, vanhusten tutkimuksessa, koululaisten keskuudessa. Kaikissa esityksissä ei kuitenkaan pohdittu, mihin näin käytetyllä huumorilla pyritään. Toisaalta, kaikki tämä saattaa olla alan tutkijoille itsestään selvyys.

Kuuntelijana koin monia ahaa-elämyksiä. Esimerkiksi sen, että huumorin tutkijalla ei tarvitse olla huumorintajua. Itse asiassa juuri huumorintajusta tai vitsinkerronnasta tuntui joillekin olevan vain haittaa, puheessa korostui esiintyminen. Sama ilmiö löytyy sananlaskututkijoiden parissa: jotkut tutkivat niitä, jotkut taas ihastuvat niihin. Monet ryhmää koskevat vitsit ja kaskut ovat ryhmään kuuluvien itsensä kertomia. Minäkin huumorintajuttomana löysin omat suosikkivitsini, jotka löytyvät aiemmin mainitusta verkko-osoitteesta Shazia Mirzan videolta. Miksi siis Shazian kaltaiset naiset ennen kulkivat miestensä jäljessä, mutta nyt viisi askelta edellä? Tämäkin selvisi, naiset kulkivat aikoinaan miesten jäljessä, sillä miehet yleensä näyttävät paremmilta siltä suunnalta katsottuina. Nykyään tilanne on siis toinen, naiset kulkevat edellä ja siihen on yksinkertainen syy: maamiinat. 
Monissa konferensseissa olen harmitellut esitysten ajankohtien päällekkäisyyksiä, kun jakaudutaan asia- tai alakohtaisiin työryhmiin. Aina tuntuu jotakin mielenkiintoista jäävän kuulematta. Tässä seminaarissa ei tätä tuskaa ollut, kaikilla luennoilla ja esitelmillä oli oma paikkansa ohjelmassa. Huumorintutkijat kokoontuivat nyt 11. kesäkouluun Tartossa. Vuonna 2012 kesäkoulu on Suomessa, sen järjestysvastuun kantaa Itä-Suomen yliopisto. Tulevan kesäkoulun kotisivut löytyvät aikanaan ISHS:n sivustoilta: <http://www.hnu.edu/ishs/>.

Kasvatustieteen tohtori ja folkloristiikan maisteri Liisa Granbom-Herranen toimii tutkijana Jyväskylän yliopistossa. 